\title{
Klebsiella terrigena, a New Species from Soil and Water
}

\author{
D. IZARD, ${ }^{1}$ C. FERRAGUT, ${ }^{1,2}$ F. GAVINI, ${ }^{1}$ K. KERSTERS, ${ }^{2}$ J. DE LEY ${ }^{2 *}$ AND H. LECLERC ${ }^{1}$ \\ Institut Pasteur de Lille, Unité Institut National de la Santé et de la Recherche Médicale 146, Université de \\ Lille II, Domaine du Centre d'Enseignement et de Recherches Techniques en Industrie Alimentaire, 59651 \\ Villeneuve d'Ascq Cédex, France, ${ }^{1}$ and Laboratorium voor Microbiologie en Microbiële Genetica, \\ Rijksuniversiteit, B-9000 Gent, Belgium ${ }^{2}$
}

Deoxyribonucleic acid (DNA)-DNA hybridization and numerical analysis of electrophoretic protein patterns were carried out to determine the taxonomic position of 37 "Klebsiella pneumoniae-like" strains from nonclinical origin (soil and water) and previously studied by numerical taxonomy (group L of Gavini et al., Ann. Microbiol. [Inst. Pasteur] 128B:45-59, 1977). The DNA interrelatedness for 20 selected strains of group L was at least $87 \%$, except for two strains (63 and $69 \%$ ). Protein electrophoretograms indicated likewise that at least $85 \%$ of the $\mathrm{L}$ strains constitute a genetically homogeneous group. The latter technique enabled the distinction of strains of group L from those of $K$. pneumoniae, $K$. oxytoca, and an unnamed Klebsiella cluster (group K) related to $K$. pneumoniae and $K$. oxytoca. On the basis of their phenotypic characters, protein electrophoretic patterns, and DNA-DNA relatedness, we propose for these strains the name Klebsiella terrigena sp. nov., with strain CIP 80-07 (= CUETM 77-176) as the type strain. The DNA of this strain was found to be 49 to $64 \%$ homologous to $K$. oxytoca DNA, 48 to $63 \%$ to $K$. pneumoniae DNA, and $51 \%$ to $K$. ozaenae DNA.

In 1977 Gavini et al. (14) showed, by a numerical analysis of the phenotypic properties of 122 strains belonging or related to the genus Klebsiella, the existence of two new groups. (i) Group $\mathrm{K}$ was related to Klebsiella pneumoniae and to $K$. oxytoca; the majority of the 24 group $\mathrm{K}$ strains were isolated from water. (ii) Group L was found to be related to $K$. pneumoniae, although the 37 strains (isolated from water or soil) possessed tetrathionate reductase and utilized $m$-hydroxybenzoate. In a more recent numerical taxonomy study of 180 strains isolated from clinical and nonclinical sources, Naemura et al. (28) confirmed the existence of group L.

The purpose of this study was to determine the homogeneity and the taxonomic position of group L (by analysis of electrophoretograms of soluble proteins and deoxyribonucleic acid [DNA]-DNA hybridization) and its genetic relationships to other genera of the family " $E n$ terobacteraceae" (not on Approved Lists of Bacterial Names [36]).

\section{MATERIALS AND METHODS}

Bacterial strains and growth media. The 177 strains used in this study are listed in Table 1. All strains labeled CUETM (Collection de l'Unité d'Ecotoxicologie Microbienne, Villeneuve d'Ascq, France) were isolates originally studied by Gavini et al. (12-15) by numerical analysis. For the preparation of DNA, cells were grown in nutrient broth at $30^{\circ} \mathrm{C}$ for $24 \mathrm{~h}$ with shaking. For the electrophoresis of soluble proteins, cells (about $2 \mathrm{~g}$, wet weight) were grown at $37^{\circ} \mathrm{C}$ for $16 \mathrm{~h}$ on nutrient agar (Oxoid) in Roux flasks.
Preparation of cell-free extracts for electrophoresis. Cell-free extracts were prepared according to the method of Kersters and De Ley (24) with the following modifications. After French pressure cell treatment, intact bacteria and debris were removed by centrifugation for $15 \mathrm{~min}$ at $30,000 \mathrm{rpm}$ and $4^{\circ} \mathrm{C}$ in a Beckman model L centrifuge (rotor type 30 ). Up to 4 $\mathrm{ml}$ of the turbid supernatant was centrifuged in a Beckman type 40 rotor for $1 \mathrm{~h}$ at $4^{\circ} \mathrm{C}$ and $35,000 \mathrm{rpm}$. A 2-ml portion of the supernatant (containing $<25 \mathrm{mg}$ of protein per $\mathrm{ml}$ ) was again centrifuged for $4 \mathrm{~h}$ at $4^{\circ} \mathrm{C}$ and $35,000 \mathrm{rpm}$. The supernatant after the last centrifugation step contained the soluble proteins; it was dialyzed overnight at $4^{\circ} \mathrm{C}$ against 1 liter of $6.4 \mathrm{mM}$ tris(hydroxymethyl)aminomethane-hydrochloride buffer, $\mathrm{pH} 9.1$, and then filtered at $4^{\circ} \mathrm{C}$ through a VCWP membrane filter $(0.1-\mu \mathrm{m}$ pore size, $25-\mathrm{mm}$ diameter; Millipore Corp.) in an Amicon 8MC apparatus under $1.5-\mathrm{kg} / \mathrm{cm}^{2}$ nitrogen pressure.

Polyacrylamide gel electrophoresis and numerical analysis of the normalized electrophoretograms. Electrophoresis of soluble proteins, densitometry, normalization of densitometric tracings, and photography were carried out as described previously (24). Each protein extract was investigated in at least three and mostly in five independent electrophoretic runs. Each normalized densitometric tracing was converted into a sequence of 130 numbers, representing the optical densities (expressed as height in millimeters) of each position on the scan. The Pearson product-moment correlation coefficient $(r)$ between each pair of densitometric tracings was calculated, and the electrophoretograms were clustered by the unweighted average pair group method, using a Siemens 7755 (BS2000) computer (24). The most typical electrophoretogram of each strain was selected as the one with the highest product of $z$ values. The $z$ transfor- 
TABLE 1. Strains used and relative binding of their DNA to $\left[{ }^{3} H\right] D N A$ of the phenotypic centrostrain CUETM 77-176

\begin{tabular}{|c|c|c|c|c|}
\hline Species (name as received) or group & Strain no. ${ }^{a}$ & $\begin{array}{l}\text { Strain no. } \\
\text { from Gavini } \\
\text { et al. }(12-15)\end{array}$ & $\begin{array}{l}\text { Origin of } \\
\text { strains }^{b}\end{array}$ & $\begin{array}{c}\% \text { Relative } \\
\text { DNA binding } \\
\text { at } 56.9^{\circ} \mathrm{C} \text { with } \\
\text { DNA of strain } \\
\text { CUETM } 77- \\
176\end{array}$ \\
\hline Group L & $\begin{array}{l}\text { CUETM 77-176 } \\
\text { CUETM 78-141 } \\
\text { CUETM 78-155 } \\
\text { CUETM 78-156 } \\
\text { CUETM 78-125 } \\
\text { CUETM 78-145 } \\
\text { CUETM 78-151 } \\
\text { CUETM 78-132 } \\
\text { CUETM 78-129 } \\
\text { CUETM 78-157 } \\
\text { CUETM 78-150 } \\
\text { CUETM 78-144 } \\
\text { CUETM 78-139 } \\
\text { CUETM 78-131 } \\
\text { CUETM 78-138 } \\
\text { CUETM 78-143 } \\
\text { CUETM 78-133 } \\
\text { CUETM 78-148 } \\
\text { CUETM 77-177 } \\
\text { CUETM 78-134 } \\
\text { CUETM 77-178 } \\
\text { CUETM 78-124 } \\
\text { CUETM 78-126 } \\
\text { CUETM 78-127 } \\
\text { CUETM 78-128 } \\
\text { CUETM 78-130 } \\
\text { CUETM 78-135 } \\
\text { CUETM 78-136 } \\
\text { CUETM 78-140 } \\
\text { CUETM 78-142 } \\
\text { CUETM 78-147 } \\
\text { CUETM 78-149 } \\
\text { CUETM 78-152 } \\
\text { CUETM 78-153 } \\
\text { CUETM 78-154 } \\
\text { CUETM 78-158 } \\
\text { CUETM 78-159 }\end{array}$ & $\begin{array}{l}\text { L } 84 \\
\text { L } 80 \\
\text { L } 66 \\
\text { L } 72 \\
\text { L } 67 \\
\text { L } 63 \\
\text { L } 81 \\
\text { L } 82 \\
\text { L } 95 \\
\text { L } 68 \\
\text { L } 102 \\
\text { L } 83 \\
\text { L } 94 \\
\text { L } 69 \\
\text { L } 78 \\
\text { L } 50 \\
\text { L } 113 \\
\text { L } 87 \\
\text { L } 28 \\
\text { L } 118 \\
\text { L } 97 \\
\text { L } 45 \\
\text { L } 89 \\
\text { L } 91 \\
\text { L } 119 \\
\text { L } 73 \\
\text { L } 85 \\
\text { L } 109 \\
\text { L } 27 \\
\text { L } 74 \\
\text { L } 49 \\
\text { L } 101 \\
\text { L } 52 \\
\text { L } 112 \\
\text { L } 108 \\
\text { L } 86 \\
\text { L } 98 \\
\text { in }\end{array}$ & $\begin{array}{l}\text { D } \\
\text { D } \\
\text { D } \\
\text { D } \\
\text { D } \\
\text { D } \\
\text { D } \\
\text { D } \\
\text { D } \\
\text { D } \\
\text { D } \\
\text { D } \\
\text { D } \\
\text { D } \\
\text { D } \\
\text { Su } \\
\text { So } \\
\text { D } \\
\text { Se } \\
\text { So } \\
\text { D } \\
\text { Su } \\
\text { D } \\
\text { D } \\
\text { Su } \\
\text { D } \\
\text { D } \\
\text { So } \\
\text { Se } \\
\text { D } \\
\text { Su } \\
\text { D } \\
\text { Su } \\
\text { So } \\
\text { So } \\
\text { D } \\
\text { D }\end{array}$ & $\begin{array}{r}100 \\
99 \\
99 \\
97 \\
97 \\
96 \\
96 \\
95 \\
95 \\
95 \\
95 \\
94 \\
94 \\
93 \\
93 \\
89 \\
88 \\
87 \\
69 \\
63 \\
\text { ND } \\
\text { ND } \\
\text { ND } \\
\text { ND } \\
\text { ND } \\
\text { ND } \\
\text { ND } \\
\text { ND } \\
\text { ND } \\
\text { ND } \\
\text { ND } \\
\text { ND } \\
\text { ND } \\
\text { ND } \\
\text { ND } \\
\text { ND } \\
\text { ND }\end{array}$ \\
\hline Group K (14) & $\begin{array}{l}\text { CUETM } 78-120 \\
\text { CUETM } 77-179 \\
\text { CUETM } 77-175^{\circ} \\
\text { CUETM } 78-115 \\
\text { CUETM } 78-118 \\
\text { CUETM } 78-119\end{array}$ & $\begin{array}{l}\text { K } 70 \\
\text { K } 43 \\
\text { K } 44 \\
\text { K } 42 \\
\text { K } 58 \\
\text { K } 117\end{array}$ & $\begin{array}{l}\text { D } \\
\text { Su } \\
\text { Su } \\
\text { Se } \\
\text { Su } \\
\text { So }\end{array}$ & $\begin{array}{r}65 \\
60 \\
\mathrm{ND} \\
\mathrm{ND} \\
\mathrm{ND} \\
\mathrm{ND}\end{array}$ \\
\hline Klebsiella oxytoca & $\begin{array}{l}\text { CUETM 78-178 } \\
\text { CUETM 78-180 } \\
\text { CUETM 78-177 } \\
\text { ATCC } 13182^{e} \\
\text { CUETM 78-179 } \\
\text { LM 25-70 } \\
\text { CUETM 78-184 } \\
\text { CUETM 78-183 } \\
\text { CUETM 79-243 } \\
\text { CUETM 78-182 } \\
\text { CUETM 78-185 }\end{array}$ & $\begin{array}{l}\text { M } 114 \\
\text { M } 115 \\
\text { M } 99 \\
\text { M } 2 \\
\text { M } 105 \\
\text { M } 92 \\
\text { M } 75 \\
\text { M } 30 \\
\text { M } 93 \\
\text { M } 104\end{array}$ & $\begin{array}{l}\text { So } \\
\text { So } \\
\text { D } \\
\text { D } \\
\\
\text { D } \\
\text { D } \\
\text { Se } \\
\text { D } \\
\text { D }\end{array}$ & $\begin{array}{l}64 \\
62 \\
60 \\
58 \\
58 \\
57 \\
57 \\
57 \\
54 \\
54 \\
49\end{array}$ \\
\hline
\end{tabular}


TABLE 1-Continued

\begin{tabular}{|c|c|c|c|c|}
\hline Species (name as received) or group & Strain no. ${ }^{a}$ & $\begin{array}{l}\text { Strain no. } \\
\text { from Gavini } \\
\text { et al. }(12-15)\end{array}$ & $\begin{array}{l}\text { Origin of } \\
\text { strains }^{b}\end{array}$ & $\begin{array}{c}\% \text { Relative } \\
\text { DNA binding } \\
\text { at } 56.9^{\circ} \mathrm{C} \text { with } \\
\text { DNA of strain } \\
\text { CUETM } 77- \\
176\end{array}$ \\
\hline Klebsiella pneumoniae & $\begin{array}{l}\text { CUETM 78-272 } \\
\text { CUETM } 77-169^{\circ} \\
\text { CUETM 78-258 } \\
\text { CUETM 78-275 } \\
\text { CUETM 80-97 } \\
\text { CUETM 78-265 } \\
\text { CUETM 78-146 } \\
\text { CUETM 78-24 } \\
\text { CUETM 78-288 } \\
\text { CUETM 78-289 } \\
\text { CUETM 77-170 } \\
\text { LM 47-70 } \\
\text { CUETM 77-180 } \\
\text { CUETM 78-284 } \\
\text { CUETM 78-51 } \\
\text { CUETM 77-181 } \\
\text { CUETM 78-264 } \\
\text { CUETM 78-271 } \\
\text { ATCC } 13882 \\
\text { CUETM 78-13 } \\
\text { CUETM 77-155 } \\
\text { CUETM 77-174 }\end{array}$ & $\begin{array}{l}\text { J } 7 \\
\text { J } 22 \\
\text { J } 9 \\
\text { J } 32 \\
\text { J } 11 \\
\text { J } 16 \\
\text { J } 77 \\
\text { D } 76 \\
\text { J } 25 \\
\text { J } 59 \\
\text { J } 21 \\
\\
\text { J } 56 \\
\text { J } 20 \\
\text { D } 30 \\
\text { J } 3 \\
\text { J } 61 \\
\text { J } 38 \\
\text { J } 1 \\
\text { D } 64 \\
\text { D } 63 \\
\text { J } 8\end{array}$ & $\begin{array}{l}\text { F } \\
\text { F } \\
\text { F } \\
\text { Se } \\
\text { F } \\
\text { F } \\
\text { D } \\
\text { Su } \\
\text { Se } \\
\text { Su } \\
\text { F } \\
\text { Su } \\
\text { F } \\
\text { Se } \\
\text { F } \\
\text { Su } \\
\text { Se } \\
\text { Su } \\
\text { Su } \\
\text { F }\end{array}$ & $\begin{array}{l}63 \\
61 \\
61 \\
59 \\
58 \\
58 \\
58 \\
58 \\
57 \\
57 \\
56 \\
56 \\
55 \\
55 \\
54 \\
53 \\
53 \\
52 \\
50 \\
50 \\
49 \\
48\end{array}$ \\
\hline Enterobacter aerogenes & $\begin{array}{l}\text { CUETM 78-186 } \\
\text { ATCC } 13048^{e} \\
\text { CDC } 3432-70 \\
\text { R 9-77 } \\
\text { NCTC 9735 } \\
\text { LM 3-70 } \\
\text { R 10-77 } \\
\text { R 6-77 } \\
\text { R } 7-77 \\
\text { R 1-78 } \\
\text { CUETM } 79-235 \\
\text { CDC 2979-69 } \\
\text { CDC 3006-67 } \\
\text { CDC 1627-66 } \\
\text { R 8-77 }\end{array}$ & c 5 & & $\begin{array}{l}63 \\
59 \\
59 \\
59 \\
58 \\
58 \\
58 \\
56 \\
54 \\
54 \\
53 \\
52 \\
51 \\
51 \\
50\end{array}$ \\
\hline Klebsiella ozaenae & CDC 276-71 & & & 51 \\
\hline "Enterobacter gergoviae" $(5,6,32)$ & $\begin{array}{l}\text { R } 3-77 \\
\text { CIP } 76-02 \\
\text { R } 2-77 \\
\text { R } 6-77\end{array}$ & & & $\begin{array}{l}48 \\
47 \\
38 \\
34\end{array}$ \\
\hline Enterobacter cloacae & $\begin{array}{l}\text { CUETM } 77-116 \\
\text { CUETM } 77-125 \\
\text { CUETM } 77-120^{\circ} \\
\text { CUETM } 78-2 \\
\text { CUETM } 78-47 \\
\text { CUETM } 78-42 \\
\text { CUETM } 77-126 \\
\text { Paris G1 } \\
\text { CDC 1347-71 } \\
\text { CUETM } 77-135 \\
\text { ATCC } 13047^{e}\end{array}$ & $\begin{array}{l}\text { G } 42 \\
\text { G } 132 \\
\text { G } 45 \\
\text { E } 29 \\
\text { E } 74 \\
\text { E } 91 \\
\text { G } 127 \\
\text { G } 13 \\
\text { G } 137\end{array}$ & $\begin{array}{l}\text { F } \\
\text { D } \\
\text { F } \\
\text { Se } \\
\text { Su } \\
\text { D } \\
\text { D }\end{array}$ & $\begin{array}{l}44 \\
41 \\
39 \\
39 \\
38 \\
35 \\
35 \\
34 \\
34 \\
31 \\
29\end{array}$ \\
\hline
\end{tabular}


TABLE 1-Continued

\begin{tabular}{|c|c|c|c|c|}
\hline Species (name as received) or group & Strain no. ${ }^{a}$ & $\begin{array}{l}\text { Strain no. } \\
\text { from Gaviri } \\
\text { et al. (12-15) }\end{array}$ & $\begin{array}{l}\text { Origin of } \\
\text { strains }^{b}\end{array}$ & $\begin{array}{c}\text { \% Relative } \\
\text { DNA binding } \\
\text { at } 56.9^{\circ} \mathrm{C} \text { with } \\
\text { DNA of strain } \\
\text { CUETM } 77- \\
176\end{array}$ \\
\hline \multirow[t]{8}{*}{ "Enterobacter amnigenus" $(18,23)$} & CUETM 78-96 & $\mathrm{H}_{3} 79$ & $\mathrm{Su}$ & 42 \\
\hline & CUETM 78-100 & $\mathrm{H}_{3} 162$ & So & 40 \\
\hline & CUETM 78-89 & $\mathrm{H}_{3} 165$ & So & 39 \\
\hline & CUETM 78-75 & $\mathrm{H}_{3} \mathrm{I} 151$ & So & 36 \\
\hline & CUETM 78-73 & $\mathrm{H}_{3} 118$ & $\mathrm{D}$ & 34 \\
\hline & $\begin{array}{l}\text { ATCC } 33072 \\
\quad(=\text { CUETM } 77-118)^{c}\end{array}$ & $\mathrm{H}_{3} 145$ & $\mathrm{Su}$ & 33 \\
\hline & CUETM 77-132 & $\mathrm{H}_{3} 130$ & $\mathrm{D}$ & 31 \\
\hline & CUETM 77-137 & $\mathrm{H}_{3} 111$ & $\mathrm{D}$ & 28 \\
\hline \multirow[t]{6}{*}{ “Enterobacter intermedium" $(18,19,22)$} & CUETM 77-145 & $\mathrm{H}_{1} \mathbf{1 0 3}$ & $\mathrm{D}$ & 42 \\
\hline & $\begin{array}{l}\text { ATCC } 33110 \quad(=\text { CIP } \\
79-27)^{c}\end{array}$ & $\mathrm{H}_{1} 86$ & $\mathrm{Su}$ & 35 \\
\hline & CUETM 77-123 & $\mathrm{H}_{1} 99$ & $\mathrm{D}$ & 34 \\
\hline & CUETM 78-87 & $\mathrm{H}_{1} 141$ & $\mathrm{D}$ & 30 \\
\hline & CUETM 77-147 & $\mathrm{H}_{1} 159$ & So & 27 \\
\hline & CUETM 77-140 & $\mathrm{H}_{1} 100$ & $\mathrm{D}$ & 22 \\
\hline \multirow[t]{3}{*}{ Levinea malonatica } & LM 2-70 & & & 39 \\
\hline & CDC 25-408 & & & 37 \\
\hline & $\mathrm{R} 35380 / 73$ & & & 30 \\
\hline \multirow[t]{2}{*}{ Levinea amalonatica } & R $17996 / 73$ & & & 38 \\
\hline & CDC 25-406 & & & 30 \\
\hline \multirow[t]{4}{*}{ Escherichia coli } & CUETM 79-193 & & & 37 \\
\hline & UWCC K12-1 & & & 31 \\
\hline & CUETM 79-197 & & & 28 \\
\hline & ATCC 10536 & & & 23 \\
\hline \multirow[t]{6}{*}{ "Rahnella aquatilis" $(18,21)$} & CUETM 77-141 & $\mathrm{H}_{2} 110$ & $\mathrm{D}$ & 27 \\
\hline & $\begin{array}{l}\text { ATCC } 33071 \quad(=\text { CIP } \\
78-65)^{c}\end{array}$ & $\mathrm{H}_{2} 133$ & $\mathrm{D}$ & 20 \\
\hline & CUETM 77-108 & $\mathbf{H}_{2} 136$ & $\mathrm{D}$ & 13 \\
\hline & CUETM 78-68 & $\mathrm{H}_{2} 163$ & So & 13 \\
\hline & CUETM 77-143 & $\mathrm{H}_{2} 106$ & $\mathrm{D}$ & 10 \\
\hline & CUETM 77-146 & $\mathrm{H}_{2} 147$ & So & 9 \\
\hline \multirow[t]{2}{*}{ Shigella sonnei } & $\begin{array}{l}\text { WRAIR I virulent } \\
(=\text { ATCC } 29930)\end{array}$ & & & 27 \\
\hline & ATCC 9290 & & & 22 \\
\hline \multirow[t]{3}{*}{ Citrobacter freundii } & $\mathrm{ATCC} 8090^{e}$ & & & 27 \\
\hline & ATCC 6750 & & & 26 \\
\hline & CDC 460-61 & & & 23 \\
\hline \multirow[t]{2}{*}{ Serratia rubidaea } & $\begin{array}{l}\text { CDC 2199-72 } \\
\quad(=\text { ATCC } 27593)\end{array}$ & & & 25 \\
\hline & CDC 934-72 & & & 18 \\
\hline \multirow[t]{2}{*}{ Serratia fonticola $(9)$} & $\begin{array}{l}\text { ATCC } 29846 \\
\quad(=\text { CUETM } 78-11)\end{array}$ & C 89 & $\mathrm{D}$ & 25 \\
\hline & ATCC 29845 & C 81 & $\mathrm{D}$ & 14 \\
\hline Providencia alcalifaciens & LM 5-70 & & & 25 \\
\hline Proteus rettgeri & LM 7-69 & & & 23 \\
\hline
\end{tabular}


TABLE 1-Continued

\begin{tabular}{|c|c|c|c|c|}
\hline Species (name as received) or group & Strain no. ${ }^{a}$ & $\begin{array}{l}\text { Strain no. } \\
\text { from Gavini } \\
\text { et al. }(12-15)\end{array}$ & $\begin{array}{l}\text { Origin of } \\
\text { strains }^{b}\end{array}$ & $\begin{array}{c}\% \text { Relative } \\
\text { DNA binding } \\
\text { at } 56.9^{\circ} \mathrm{C} \text { with } \\
\text { DNA of strain } \\
\text { CUETM } 77- \\
176\end{array}$ \\
\hline Erwinia amylovora & ATCC $15580^{e}$ & & & 37 \\
\hline "Enterobacter sakazakii" $(5,37)$ & $\begin{array}{l}\text { R } 20-77 \\
\text { R } 16-76 \\
\text { R } 20-73 \\
\text { R } 2-78 \\
\text { R } 3-74\end{array}$ & & & $\begin{array}{l}35 \\
31 \\
29 \\
26 \\
20\end{array}$ \\
\hline Serratia plymuthica $(16,17)$ & $\begin{array}{l}\text { CUETM 78-218 } \\
\text { B } 3617\end{array}$ & $\mathrm{SB}_{1} 62$ & $\mathbf{D}$ & $\begin{array}{l}34 \\
12\end{array}$ \\
\hline Serratia marcescens & $\begin{array}{l}\text { CDC } 868-57 \\
\text { ATCC } 13880^{e} \\
\text { LM } 1-63\end{array}$ & & & $\begin{array}{l}31 \\
28 \\
26\end{array}$ \\
\hline Salmonella typhimurium & $\begin{array}{l}\text { ATCC } 23565 \\
\text { UWCC LT2 }\end{array}$ & & & $\begin{array}{l}30 \\
25\end{array}$ \\
\hline Shigella dysenteriae & WRAIR A1 & & & 29 \\
\hline Shigella flexneri & $\begin{array}{l}\text { ATCC } 12661 \\
\text { LM 15-76 }\end{array}$ & & & $\begin{array}{l}29 \\
26\end{array}$ \\
\hline Serratia liquefaciens & $\begin{array}{l}\text { LM 13-70 } \\
\text { CUETM 78-197 }\end{array}$ & $\mathrm{SB}_{2} 70$ & $\mathrm{D}$ & $\begin{array}{l}28 \\
18\end{array}$ \\
\hline Erwinia dissolvens & ATCC $23373^{e}$ & & & 17 \\
\hline Hafnia alvei & $\begin{array}{l}\text { LM 51-70 } \\
\text { CUETM 78-268 } \\
\text { CUETM 78-267 } \\
\text { CUETM 77-171 } \\
\text { CUETM } 77-144^{c} \\
\text { ATCC } 13337^{e}\end{array}$ & $\begin{array}{l}\text { I } 120 \\
\text { I } 71 \\
\text { I } 94 \\
\text { I } 114\end{array}$ & $\begin{array}{l}\mathrm{D} \\
\mathrm{Se} \\
\mathrm{Su} \\
\mathrm{D}\end{array}$ & $\begin{array}{r}15 \\
11 \\
9 \\
9 \\
8 \\
8\end{array}$ \\
\hline Proteus morganii & LM 11-70 & & & 15 \\
\hline Proteus mirabilis & $\begin{array}{l}\text { LM 3-69 } \\
\text { ATCC } 9240\end{array}$ & & & $\begin{array}{l}12 \\
11\end{array}$ \\
\hline Proteus vulgaris & $\begin{array}{l}\text { LM 3-70 } \\
\text { ATCC } 13315^{e}\end{array}$ & & & $\begin{array}{r}11 \\
8\end{array}$ \\
\hline
\end{tabular}

${ }^{a}$ Abbreviations: ATCC, American Type Culture Collection, Rockville, Md., U.S.A.; B, J. Brisou, Université de Poitiers, Poitiers, France; CDC, Center for Disease Control, Atlanta, Ga., U.S.A.; CIP, Collection de l'Institut Pasteur, Paris, France; CUETM, Collection de l'Unité d'Ecotoxicologie Microbienne, Villeneuve d'Ascq, France: LM, L. Le Minor, Institut Pasteur, Paris, France; NCTC, National Collection of Type Cultures, London, England; Paris, Collection des Entérobactéries, Institut Pasteur, Paris, France; R. C. Richard, Institut Pasteur, Paris, France; UWCC, University of Washington Culture Collection, Seattle, Wash., U.S.A.; WRAIR, Walter Reed Army Institute of Research, Washington, D.C., U.S.A.

${ }^{b}$ Origin: D, drinking waters; F, fecal samples; Se, sewage; So, unpolluted soils; Su, surface waters.

c Phenotypic centrostrain.

${ }^{d}$ ND, Not determined.

e Type strain.

mation is the inverse hyperbolic tangent of the correlation coefficient $r$ (33). However, in a few cases we selected the gel with the second highest product of $z$ values as the most typical one, after visual comparison of the normalized photographs. In the final numerical analysis, only the most representative electrophoretogram per strain was used. The homogeneity of group L was determined by calculation of the hierarchical 
order, $H$, of each electrophoretogram, $H$ being the product of all of the $z$ values of each strain $(35,38)$.

DNA-DNA hybridizations. The strain chosen for DNA labeling with $\left[{ }^{3} \mathrm{H}\right]$ thymidine was the phenotypic "centrostrain" (i.e., the strain phenotypically most similar to the others in a taxon) CUETM 77-176 (L $84 ; 14)$. The extraction and purification of both labeled and unlabeled DNA were performed according to Marmur's method (27) as slightly modified by Ferragut and Leclerc (10). DNA-DNA reassociation was carried out by competition reaction in the conditions used by De Ley and Tytgat (7) and previously described $(11,12,21,22)$. The average guanine-pluscytosine content of labeled CUETM 77-176 DNA, determined as previously described $(9,10,18)$, was $56.7 \mathrm{~mol} \%$ (four determinations). The optimal temperature of renaturation calculated from De Ley and Tytgat's equation (7) was $56.9^{\circ} \mathrm{C}$.

\section{RESULTS}

Comparison of electrophoretic protein patterns of 52 Klebsiella strains. Electrophoretograms were prepared from the 37 strains belonging to group L, 6 strains of group $\mathrm{K}, 6$ strains of $K$. pneumoniae (group J of Gavini et al. [14]), and 3 strains of $K$. oxytoca (group $M$ of Gavini et al. [14]). More than 200 normalized electrophoretograms of 52 Klebsiella strains were compared by numerical analysis. The lower reproducibility limits were above $r=0.96$ for 42 strains and above $r=0.94$ for the remaining 10 strains.

The final numerical analysis is represented as a sorted and shaded matrix of correlation coefficients (Fig. 1). The following four groups of Klebsiella strains could be distinguished by protein electrophoresis: $K$. oxytoca (group M), $K$. pneumoniae (group J), group $\mathrm{K}$, and group $\mathrm{L}$. Normalized protein electrophoretograms of 15 representative strains of these four Klebsiella groups are shown in Fig. 2. The great electrophoretic homogeneity within group $L$ is apparent from Fig. 1, with the exception of the following five strains: CUETM 77-177, 78-134, 78-127, 78-149, and 78-154 (Fig. 1 and 2). Repeating the experiments did not change the results. Both numerical analysis (Fig. 1) and visual comparison of normalized photographs (Fig. 2) showed that strains CUETM 77-177 and CUETM 78134 belong to group $\mathrm{K}$. Within group L, strain CUETM 78-126 had the highest value of hierarchical order $H$ and can therefore be considered the most representative strain of group $L$ on the basis of protein electrophoretic patterns.

DNA-DNA hybridization. The DNA-DNA hybridization values between the phenotypic centrostrain CUETM 77-176 of group L and 19 other isolates of the same group were determined (Table 1). The strains of group $L$ formed a very tight hybridization group. The relative binding ratio within the group was at least $87 \%$, except for two strains (CUETM 77-177, 69\%; CUETM 78-134, 63\%).

To determine the taxonomic position of group $L$, hybridization values were measured between the centrostrain and a great number of strains belonging to Klebsiella and other, related genera (Table 1). Strain CUETM 77-176 shared 60 to $65 \%$ of its genome with two strains of group $\mathrm{K}$ related to the genus Klebsiella, 49 to $64 \%$ with $K$. oxytoca (11 strains used), 48 to $63 \%$ with $K$. pneumoniae (21 strains used), and $51 \%$ with $K$. ozaenae (1 strain). The DNA relatedness values were in the range 8 to $48 \%$ for all of the other species investigated except for Enterobacter aerogenes. Hybridization between DNA of strain CUETM 77-176 and 15 strains of $E$. aerogenes yielded a degree of reassociation of 50 to $63 \%$. The other organisms belonging to the genus Enterobacter yielded moderate to low values: 34 to $48 \%$ hybridization with " $E$. gergoviae" (not on Approved Lists [36]) $(5,6,32), 29$ to $44 \%$ with $E$. cloacae, 28 to $42 \%$ with " $E$. amnigenus" (not on Approved Lists [36]) (13, 18,23 ), 22 to $42 \%$ with " $E$. intermedium" (not on Approved Lists [36]) $(13,18,19,22)$, and 20 to $35 \%$ with "E. sakazakii" (not on Approved Lists [36]) $(5,37)$. The levels of hybridization indicated a significant difference from members of the genera Levinea (30 to $39 \%$ ), Escherichia, and Shigella (22 to $37 \%$ ), Serratia (12 to $34 \%$ ), and Citrobacter (23 to $27 \%$ ). The lowest degree of hybridization existed between group $\mathrm{L}$ and representative strains of the genera Providencia (25\%), Proteus (8 to 23\%), Hafnia (8 to $15 \%$ ), and "Rahnella" (not on Approved Lists [36]) (9 to $27 \%)(13,18,21)$.

\section{DISCUSSION}

Group L was originally described by Gavini et al. (14), and its existence among other Klebsi. ella-like organisms from nonclinical origin was later confirmed by Naemura et al. (28). The 37 strains constituting group $L$ have been isolated from sewage, surface water, drinking water, and unpolluted soils (14). They were considered to be related to $K$. pneumoniae on the basis of phenotypic characteristics (14). Later the DNADNA hybridization data of Ferragut and Leclerc (11) showed that two L-strains were 48 to $59 \%$ related to $K$. pneumoniae. Our paper clarifies the taxonomic status of group $\mathrm{L}$ within the genus Klebsiella.

Eighteen of 20 selected L-strains had DNADNA reassociation values of at least $87 \%$ with the phenotypic centrostrain CUETM 77-176 (Table 1). Thirty-two of the $37 \mathrm{~L}$-strains displayed very similar and sometimes almost identical protein electrophoretograms (Fig. 1 and 2). 
Because bacteria with very similar protein patterns are genetically highly related $(24,25)$, the combined results of phenotypic features, protein electrophoresis, and DNA-DNA hybridization indicate that the majority of L-strains constitute a genetically homogeneous group.

Five L-strains (CUETM 77-177, 78-134, 78127, 78-149, and 78-154) exhibited an aberrant

\begin{tabular}{|c|c|}
\hline $\begin{array}{l}\text { CUETM } \\
\text { CUE TM } \\
\text { ATC C } \\
\text { CUE TM } \\
\text { CUETM } \\
\text { ATCC }\end{array}$ & $\begin{array}{l}78-180 \\
78-182 \\
13182 \\
78-288 \\
77-181 \\
13882\end{array}$ \\
\hline CUETM & $77-169$ \\
\hline $\begin{array}{l}\text { CUE TM } \\
\text { CUETM } \\
\text { CUETM } \\
\text { CUE TM } \\
\text { CUETM } \\
\text { CUE TM } \\
\text { CUE TM } \\
\text { CUE TM } \\
\text { CUE TM } \\
\text { CUE TM } \\
\text { CUE TM }\end{array}$ & $\begin{array}{l}77-180 \\
77-174 \\
77-177 \\
77-179 \\
78-119 \\
78-134 \\
78-115 \\
78-120 \\
77-175 \\
78-118 \\
78-125\end{array}$ \\
\hline $\begin{array}{l}\text { CUETM } \\
\text { CUE TM } \\
\text { CUETM } \\
\text { CUETM } \\
\text { CUETM } \\
\text { CUETM } \\
\text { CUETM } \\
\text { CUETH } \\
\text { CUETM } \\
\text { CUETM }\end{array}$ & $\begin{array}{l}78-148 \\
78-145 \\
78-143 \\
78-136 \\
78-135 \\
78-124 \\
78-131 \\
77-176 \\
78-155 \\
78-151\end{array}$ \\
\hline $\begin{array}{l}\text { CUETM } \\
\text { CUETM } \\
\text { CUETM } \\
\text { CUETH } \\
\text { CUETM } \\
\text { CUETM } \\
\text { CUE TM } \\
\text { CUE TM } \\
\text { CUETM } \\
\text { CUE TM } \\
\text { CUETM }\end{array}$ & $\begin{array}{l}78-126 \\
78-152 \\
78-141 \\
78-158 \\
78-130 \\
78-142 \\
78-139 \\
78-159 \\
78-150 \\
77-178 \\
78-153\end{array}$ \\
\hline $\begin{array}{l}\text { CUE TM } \\
\text { CUETM } \\
\text { CUE TM } \\
\text { CUE TM } \\
\text { CUE TM } \\
\text { CUE TM }\end{array}$ & $\begin{array}{l}78-129 \\
78-132 \\
78-133 \\
78-157 \\
78-156 \\
78-144\end{array}$ \\
\hline $\begin{array}{l}\text { CUETM } \\
\text { CUETM } \\
\text { CUETH }\end{array}$ & $\begin{array}{l}78-144 \\
78-128 \\
78-140 \\
78-147\end{array}$ \\
\hline CUE TH & $78-138$ \\
\hline $\begin{array}{l}\text { CUETM } \\
\text { CUETM } \\
\text { CUETM }\end{array}$ & $\begin{array}{l}78-127 \\
78-154 \\
78-149\end{array}$ \\
\hline
\end{tabular}

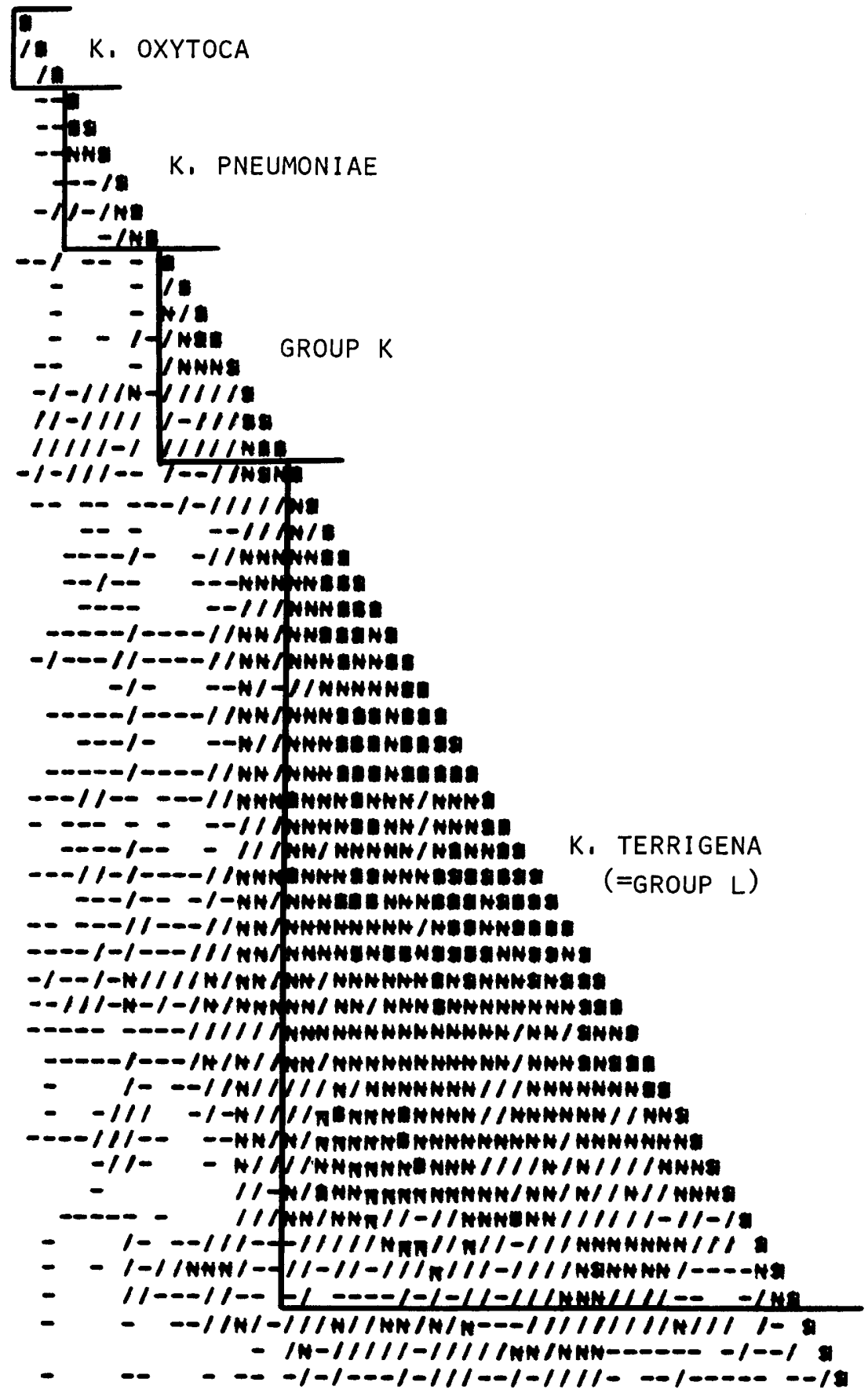

Fig. 1. Sorted and differentially shaded matrix of correlation coefficients based on the numerical analysis of protein electrophoretograms from 52 Klebsiella strains. The range of correlation coefficients $(r)$ is symbolized as: $\$$, 0.96 to $1.0 ; \mathrm{N}, 0.92$ to $0.95 ;$ /, 0.88 to $0.91 ;-, 0.84$ to 0.87 ; open space, <0.84. 
protein pattern. The electrophoretograms of strains CUETM 77-177 and 78-134 were very similar to the patterns of group $\mathrm{K}$ strains (Fig. 1 and 2). The hybridization values (63 to $69 \%$ ) of both strains with the phenotypic centrostrain of group L (CUETM 77-176; Table 1) are in agreement with the classification based on the electrophoretograms, because two authentic Kstrains (CUETM 78-120 and 77-179) hybridize with strain CUETM 77-176 at a level (60 to $65 \%$ ) comparable to that at which strains CUETM 77177 and 78-134 hybridize with CUETM 77-176 (Table 1). A reexamination of the results of Gavini et al. (14) indicates that both strains display phenotypic similarities with each other (Fig. 1 of reference 14) and that strain CUETM 77-177 is phenotypically most removed from all of the other strains of group L. The exact taxo-

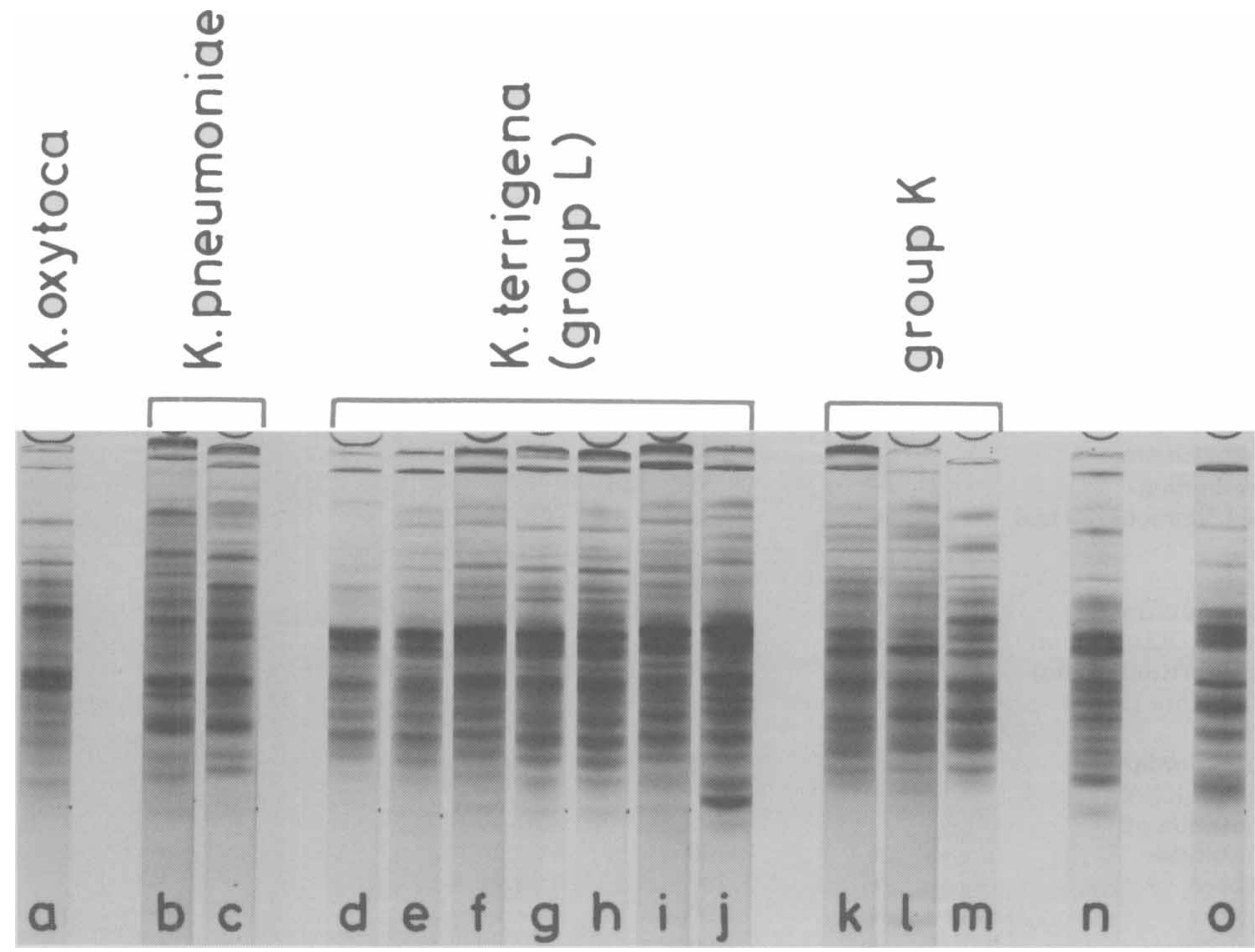

FIG. 2. Normalized protein electrophoretograms of 15 Klebsiella strains: (a) K. oxytoca CUETM 78-182; K. pneumoniae (b) ATCC 13882 and (c) CUETM 77-181; K. terrigena (group L) (d) CUETM 77-176, (e) CUETM 78-155, (f) CUETM 78-151, (g) CUETM 78-159, (h) CUETM 78-125, (i) CUETM 78-136, and (j) CUETM 78154; Klebsiella-like strains (group K) (k) CUETM 78-120, (l) CUETM 78-134, and (m) CUETM 77-177; unclassified Klebsiella strains (n) CUETM 78-127 and (o) CUETM 78-149.

TABLE 2. Characteristics useful in differentiating the species of the genus Klebsiella $(2,14,29,30,31)$

\begin{tabular}{|c|c|c|c|c|c|c|}
\hline Characteristic & K. pneumoniae & K. oxytoca & K. terrigena & K. ozaenae & K. rhinoscleromatis & K. mobilis \\
\hline \multicolumn{7}{|l|}{ Growth at: } \\
\hline $4^{\circ} \mathrm{C}$ & $-^{a}$ & - & + & & & $(+)$ \\
\hline $41^{\circ} \mathrm{C}$ & + & + & - & & & + \\
\hline \multicolumn{7}{|l|}{ Presence of: } \\
\hline Urease & + & + & + & $\mathrm{d}$ & - & - \\
\hline$\beta$-Galactosidase & + & + & + & + & - & + \\
\hline Formation of indole & - & + & - & - & - & - \\
\hline $\begin{array}{l}\text { Voges-Proskauer reac- } \\
\text { tion }\end{array}$ & + & + & + & - & - & + \\
\hline $\begin{array}{l}m \text {-Hydroxybenzoate as } \\
\text { carbon source }\end{array}$ & - & + & + & & & + \\
\hline
\end{tabular}

${ }^{a}$ Symbols: + , Positive reaction for at least $90 \%$ of the strains within $24 \mathrm{~h}$ to $48 \mathrm{~h}$; - , negative reaction for at least $90 \%$ of the strains; $d$, different biochemical types $(+$ or -$) ;(+)$, slow positive reaction. 
TABLE 3. Phenotypic characteristics of K. terrigena strains (group L) (14; unpublished data)

\begin{tabular}{|c|c|c|c|c|}
\hline \multirow{2}{*}{ Characteristic } & \multicolumn{3}{|c|}{ Group L (33 strains) } & \multirow{2}{*}{$\begin{array}{c}\text { Type strain (CIP } 80.07=\text { CUETM } \\
77-176)_{\text {reaction }}{ }^{a}\end{array}$} \\
\hline & Reaction $^{a}$ & $\%$ Positive & \% Slowly positive ${ }^{b}$ & \\
\hline \multicolumn{5}{|l|}{ Growth at: } \\
\hline $4^{\circ} \mathrm{C}$ & + & 91 & 6 & +4 \\
\hline $41^{\circ} \mathrm{C}$ & - & 0 & & - \\
\hline $44.5^{\circ} \mathrm{C}$ & - & 0 & & - \\
\hline Motility $\left(30\right.$ and $\left.37^{\circ} \mathrm{C}\right)$ & - & 0 & & - \\
\hline Lysine decarboxylase & + & 100 & & + \\
\hline Arginine dihydrolase & - & 0 & & - \\
\hline Ornithine decarboxylase & - & 0 & & - \\
\hline Gelatinase $\left(20^{\circ} \mathrm{C}\right)$ & - & 0 & & - \\
\hline Urease & + & 100 & & + \\
\hline$\beta$-Galactosidase & + & 100 & & + \\
\hline$\beta$-Xylosidase & + & 100 & & + \\
\hline Deoxyribonuclease & - & 0 & & - \\
\hline Tetrathionate reductase & + & 94 & & + \\
\hline Phenylalanine deaminase & - & 0 & & - \\
\hline Chitinolysis & - & 0 & & - \\
\hline Tween 80 hydrolysis & - & 0 & & - \\
\hline Indole & - & 0 & & - \\
\hline $\begin{array}{l}\text { Methyl red test ( } 30 \text { and } \\
37^{\circ} \mathrm{C} \text { ) }\end{array}$ & + & 100 & & + \\
\hline $\begin{array}{l}\text { Voges-Proskauer reaction } \\
\left(30 \text { and } 37^{\circ} \mathrm{C}\right)\end{array}$ & + & 100 & & + \\
\hline Nitrate to nitrite & + & 100 & & + \\
\hline $\mathrm{H}_{2} \mathrm{~S}$ production & - & 0 & & - \\
\hline $\begin{array}{l}\text { Citrate (Simmons; } 30 \text { and } \\
\left.37^{\circ} \mathrm{C}\right)\end{array}$ & + & 100 & & +2 \\
\hline Malonate & + & 100 & & + \\
\hline Mucate (Kauffmann) & + & 100 & & + \\
\hline D-Tartrate (Kauffmann) & - or + & 15 & & - \\
\hline L-Tartrate (Kauffmann) & - or + & 15 & & - \\
\hline $\begin{array}{l}\text { meso-Tartrate (Kauff- } \\
\text { mann) }\end{array}$ & - or + & 12 & & + \\
\hline Tartrate (Jordan) & + or - & 73 & & - \\
\hline Growth on KCN & + & 100 & & + \\
\hline \multicolumn{5}{|l|}{ Fermentation of: } \\
\hline L-Arabinose & + & 100 & & + \\
\hline D-Ribose & + & 100 & & + \\
\hline D-Xylose & + & 100 & & + \\
\hline D-Galactose & + & 100 & & + \\
\hline D-Glucose (gas) & + & 100 & & + \\
\hline D-Mannose & + & 100 & & + \\
\hline L-Rhamnose & + & 100 & & + \\
\hline D-Fructose & + & 100 & & + \\
\hline$\alpha$-Methyl-D-glucoside & + & 100 & & + \\
\hline $\begin{array}{l}\text { Cellobiose (acid and } \\
\text { gas) }\end{array}$ & + & 100 & & + \\
\hline Lactose & + & 100 & & + \\
\hline Maltose & + & 100 & & + \\
\hline Melibiose & + & 100 & & + \\
\hline Raffinose & + & 100 & & + \\
\hline Sucrose & + & 100 & & + \\
\hline Trehalose & + & 100 & & + \\
\hline Glycerol (gas) & + & 100 & & + \\
\hline Adonitol & + & 100 & & + \\
\hline meso-Inositol & + & 100 & & + \\
\hline D-Mannitol & + & 100 & & + \\
\hline Sorbitol & + & 100 & & + \\
\hline Dextrin & + & 100 & & + \\
\hline Esculin & + & 100 & & + \\
\hline Salicin & + & 100 & & + \\
\hline
\end{tabular}


TABLE 3-Continued

\begin{tabular}{|c|c|c|c|c|}
\hline \multirow{2}{*}{ Characteristic } & \multicolumn{3}{|c|}{ Group L (33 strains) } & \multirow{2}{*}{$\begin{array}{c}\text { Type strain (CIP } 80.07=\text { CUETM } \\
77-176) \text { reaction }\end{array}$} \\
\hline & Reaction $^{a}$ & $\%$ Positive & $\%$ Slowly positive & \\
\hline L-Sorbose & + & 97 & & + \\
\hline Melezitose & + & 97 & & + \\
\hline Inulin & $(+)$ or - & & 82 & +7 \\
\hline Glycogen & d & 18 & 6 & - \\
\hline Dulcitol & - & 6 & & - \\
\hline meso-Erythritol & - & 0 & & - \\
\hline Pectin & - & 0 & & - \\
\hline Starch & - & 0 & & - \\
\hline
\end{tabular}

${ }^{a}$ Symbols: + , Positive reaction within 24 to $48 \mathrm{~h} ;+$ or,-- or,$+(+)$ or - , the first sign corresponds to the most frequent result; -, negative reaction. Numbers after symbols indicate number of days for reaction to take place.

${ }^{b}$ Positive reaction between 2 and 30 days.

nomic positions of strains CUETM 78-127, 78149 , and 78-154 remain to be determined. Strain CUETM 78-154 probably belongs to group L because its protein pattern displays great overall similarities with those of the other L-strains (Fig. 2). Numerical analysis (Fig. 1) places this strain outside group $L$ because its electrophoretogram contains one heavier protein band in the lower part of the gel (Fig. 2).

A numerical analysis of the phenotypic features (14), the protein electrophoretograms, and the results of DNA-DNA hybridizations permit the differentiation of group L from $K$. oxytoca, $K$. pneumoniae, and the Klebsiella-like group $K$. The DNA relatedness with the other species studied was lower than $48 \%$, except for $E$. aerogenes (50 to $63 \%$ ). According to Bascomb et al. (2) and Izard et al. (20), E. aerogenes should be classified in the genus Klebsiella. The latter species can be found on the Approved Lists (36) as both $E$. aerogenes and $K$. mobilis, with the same type strain, ATCC 13048. The range of DNA reassociation values between group $L$ and the Klebsiella species (48 to $63 \%$, Table 1) is higher than the intrageneric relatedness level (35 to 55\%) proposed by Brenner et al. (4) for the family.

The three methods combined indicate that, on phenotypic and genotypic grounds, group L should be considered a homogeneous and distinct taxon within the genus Klebsiella. We therefore propose group $L$ as a new species, Klebsiella terrigena (ter.ri.ge'na. L.n. terra soil; L. suffix gena origin; M.L.n. terrigena from soil) because of the environmental origin of the isolates (soil, water). We now suggest that the genus Klebsiella should contain the following six species: (i) $K$. pneumoniae (Schroeter 1886) Trevisan $1887(34,39)$, (ii) $K$. ozaenae (Abel 1893) Bergey, Harrison, Breed, Hammer, and Huntoon $1925(1,3)$, (iii) $K$. rhinoscleromatis Trevisan 1887 (39), (iv) K. oxytoca (Flügge 1886)
Lautrop 1956 (26), (v) K. mobilis Bascomb, Lapage, Willcox, and Curtis 1971 (2), and (vi) $K$. terrigena sp. nov.

The phenotypic features used in differentiating the species of the genus Klebsiella are listed in Table 2.

Description of Klebsiella terrigena sp. nov. The description of this new species is based on 33 strains of group L from Gavini et al. (14); their L-strains CUETM 78-134, CUETM 77-177, CUETM 78-127, and 78-149 do not belong in this new species (see above).

Cell characteristics. Gram-negative, nonmotile, nonsporeforming, straight rods measuring 0.3 to 1.5 by 0.6 to $6-0 \mu \mathrm{m}$.

Colonial characteristics. Colonies on nutrient agar are smooth, more or less dome shaped, and of varying degrees of stickiness.

Culture conditions. Growth occurs on nutrient agar at 30 and $37^{\circ} \mathrm{C}$ but not at $41^{\circ} \mathrm{C}$.

Relationships to oxygen. Facultatively anaerobic.

Biochemical characteristics. The biochemical features (14) are summarized in Table 3.

Nutritional characteristics. The following carbon sources are utilized (by 80 to $100 \%$ of the strains) (14): L-arabinose, D-ribose, D-xylose, Lrhamnose, D-fructose, D-galactose, D-glucose, $D$ mannose, cellobiose, lactose, maltose, sucrose, trehalose, starch, gluconate, mucate, salicin, glycerol, adonitol, D-mannitol, meso-inositol, sorbitol, acetate, DL-lactate, DL-glycerate, Dmalate, L-malate, pyruvate, citrate, malonate, succinate, fumarate, phenylacetate, benzoate, $m$ hydroxybenzoate, $p$-hydroxybenzoate, D-quinate, $\mathrm{L}$-aspartate, L-glutamate, $\mathrm{L}$ - $\alpha$-alanine, $\mathrm{D}-\alpha$ alanine, L-serine, L-proline, L-histidine, histamine, and putrescine.

The following carbon sources are not utilized (by 80 to $100 \%$ of the strains within 5 days): Darabinose, D-fucose, inulin, ethanol, methanol, 
n-propanol, isopropanol, geraniol, 2,3-butylene glycol, meso-erythritol, dulcitol, ethylene glycol, propylene glycol, propionate, D-tartrate, itaconate, aconitate, oxalate, pimelate, suberate, azelate, levulinate, 2-keto-glutarate, glutarate, adipate, sebacate, salicylate, butyrate, isobutyrate, $n$-valerate, isovalerate, $n$-caproate, heptanoate, pelargonate, caprate, D-mandelate, L-mandelate, phthalate, isophthalate, terephthalate, phenol, benzyl formate, glycine, $\beta$-alanine, L-leucine, Lisoleucine, L-valine, L-lysine, L-citrulline, L-threonine, L-cysteine, L-methionine, DL-2-aminobutyrate, DL-3-aminobutyrate, DL-5-aminovalerate, L-phenylalanine, L-tyrosine, 2 -aminobenzoate, 3-aminobenzoate, 4-aminobenzoate, D-tryptophan, L-tryptophan, spermine, amylamine, ethanolamine, butylamine, benzylamine, diphenylamine, urea, urate, sarcosine, betaine, creatine, pantothenate, nicotinate, trigonelline, naphthalene, dodecane, and hexadecane.

Genetic data. The average guanine-plus-cytosine content of the DNA of the type strain, CIP $80-07$, is $56.7 \mathrm{~mol} \%$. Genetic relatedness (DNA-DNA hybridization) with the most related species is as follows: $K$. oxytoca, 49 to $64 \%$ (11 strains used); K. pneumoniae, 48 to $63 \%$ (21 strains used); $E$. aerogenes, 50 to $63 \%$ (15 strains used); and $K$. ozaenae, $51 \%$ (1 strain used).

Habitat. Found in unpolluted soils and water (drinking water, surface water).

Type strain. Gavini L 84 = CUETM 77-176 $=$ CIP (Collection de l'Institut Pasteur, Paris, France) 80-07. Isolated from drinking water. The characteristics of the type strain are those given above for the species; the biochemical characteristics are presented in Table 3.

\section{ACKNOWLEDGMENTS}

We thank E. Dewailly, A. Bernigaud, D. Dewettinck, and $\mathrm{U}$. Torck for technical assistance.

K.K. is indebted to the Nationaal Fonds voor Wetenschappelijk Onderzoek, Belgium, for a Krediet aan Navorser, and J.D.L. is indebted to the Fonds voor Kollektief Fundamenteel Onderzoek for research and personnel grants.

\section{REPRINT REQUESTS}

Address reprint requests to: Daniel Izard, Unité INSERM 146, Domaine du C.E.R.T.I.A., B.P. 39, 59651 Villeneuve d'Ascq Cedex, France.

\section{LITERATURE CITED}

1. Abel, R. 1893. Bakteriologische Studien über Ozaena simplex. Zentralbl. Bakteriol. Parasitenkd. Infektionskr. Hyg. Abt. 1 Orig. 13:161-173.

2. Bascomb, S., S. P. Lapage, W. R. Willcox, and M. A. Curtis. 1971. Numerical classification of the tribe Klebsielleae. J. Gen. Microbiol. 66:279-295.

3. Bergey, D. H., F. C. Harrison, R. S. Breed, B. W. Hammer, and F. M. Huntoon. 1925. Bergey's manual of determinative bacteriology, 2nd ed. The Williams \& Wilkins Co., Baltimore.

4. Brenner, D. J. 1979. Speciation in Yersinia. Contrib. Microbiol. Immunol. 5:33-43.

5. Brenner, D. J., J. J. Farmer III, F. W. Hickman,
M. A. Asbury, and A. G. Steigerwalt. 1977. Taxonomic and nomenclature changes in Enterobacteriaceae. Publication no. 78-8356. Centers for Disease Control, Atlanta.

6. Brenner, D. J., C. Richard, A. G. Steigerwalt, M. A. Asbury, and M. Mandel. 1980. Enterobacter gergoviae sp. nov.: a new species of Enterobacteriaceae found in clinical specimens and the environment. Int. J. Syst. Bacteriol. 30:1-6.

7. De Ley, J., and R. Tytgat. 1970. Evaluation of membrane filter methods for DNA:DNA hybridization. Antonie van Leeuwenhoek J. Microbiol. Serol. 36:461-474.

8. Farmer, J. J., III, M. A. Asbury, F. W. Hickman, D. J. Brenner, and the Enterobacteriaceae Study Group. 1980. Enterobacter sakazakii: a new species of "Enterobacteriaceae" isolated from clinical specimens. Int. J. Syst. Bacteriol. 30:569-584.

9. Ferragut, C., F. Gavini, D. Izard, and H. Leclerc. 1978. Etude du \%GC dans un groupe d'entérobactéries $\mathrm{H}_{2} \mathrm{~S}^{-}$, apparentées au genre Citrobacter. Can. J. Microbiol. 24:473-479.

10. Ferragut, C., and H. Leclerc. 1976. Etude comparative des méthodes de détermination du Tm de l'ADN bactérien. Arn. Microbiol. (Inst. Pasteur) 127 A:223-235.

11. Ferragut, C., and $H$. Leclerc. 1978. Characterization of motile and acetoin-negative Klebsiella pneumoniae strains by DNA:DNA hybridization. Antonie van Leeuwenhoek J. Microbiol. Serol. 44:407-424.

12. Gavini, F., C. Ferragut, D. Izard, P. A. Trinel, H. Leclerc, B. Lefèbvre, and D. A. A. Mossel. 1979. Serratia fonticola, a new species from water. Int. J. Syst. Bacteriol. 29:92-101.

13. Gavini, F., C. Ferragut, and H. Leclerc. 1976. Etude taxonomique d'entérobactéries appartenant ou apparentées au genre Enterobacter. Ann. Microbiol. (Inst. Pasteur) 127B:317-335.

14. Gavini, F., H. Leclerc, B. Lefèbvre, C. Ferragut, and D. Izard. 1977. Etude taxonomique d'entérobactéries appartenant ou apparentées au genre Klebsiella. Ann. Microbiol. (Inst. Pasteur) 128B:45-59.

15. Gavini, F., B. Lefèbvre, and H. Leclerc. 1976. Positions taxonomiques d'entérobactéries $\mathrm{H}_{2} \mathrm{~S}^{-m}$ par rapport au genre Citrobacter. Ann. Microbiol. (Inst. Pasteur) 127A:275-295.

16. Grimont, P. A. D., F. Grimont, H. L. C. Dulong de Rosnay, and P. H. A. Sneath. 1977. Taxonomy of the genus Serratia. J. Gen. Microbiol. 98:39-66.

17. Grimont, P. A. D., F. Grimont, C. Richard, B. R. Davis, A. G. Steigerwalt, and D. J. Brenner. 1978. Deoxyribonucleic acid relatedness between Serratia plymuthica and other Serratia species, with a description of Serratia odorifera sp. nov. (type strain: ICPB 3995). Int. J. Syst. Bacteriol. 28:453-463.

18. Izard, D., C. Ferragut, F. Gavini, and H. Leclerc. 1978. Variations of the moles percent guanine plus cytosine within a group of Enterobacteriaceae belonging or related to the genus Enterobacter. Int. J. Syst. Bacteriol. 28:449-452.

19. Izard, D., F. Gavini, and H. Leclerc. 1979. Polynucleotide sequence relatedness and genome size among $E n$ terobacter intermedium sp. nov. and the species Enterobacter cloacae and Klebsiella pneumoniae. Zentralbl. Bakteriol. Parasitenkd. Infektionskr. Hyg. Abt. 1 Orig. Reihe C 1:51-60.

20. Izard, D., F. Gavini, P. A. Trinel, F. Krubwa, and H. Leclerc. 1980. Contribution of DNA-DNA hybridization to the transfer of Enterobacter aerogenes to the genus Klebsiella as K. mobilis. Zentralbl. Bakteriol. Parasitenkd. Infektionskr. Hyg. Abt. 1 Orig. Reihe C 1: 257-263.

21. Izard, D., F. Gavini, P. A. Trinel, and H. Leclerc. 1979. Rahnella aquatilis, nouveau membre de la famille des Enterobacteriaceae. Ann. Microbiol. (Inst. Pasteur) 130A:163-177. 
22. Izard, D., F. Gavini, P. A. Trinel, and H. Leclerc. 1979 Etude d'un groupe nouveau d'Enterobacteriaceae (groupe $\mathrm{H}_{1}$ ) apparenté à l'espèce Enterobacter cloacae. Can. J. Microbiol. 25:713-718.

23. Izard, D., F. Gavini, P. A. Trinel, and H. Leclerc. 1980 Deoxyribonucleic acid relatedness between Enterobac. ter cloacae and Enterobacter amnigenus sp. nov. Int. J. Syst. Bacteriol. 31:35-42.

24. Kersters, K., and J. De Ley. 1975. Identification and grouping of bacteria by numerical analysis of thei electrophoretic protein patterns. J. Gen. Microbiol. 87; 333-342.

25. Kersters, K., and J. De Ley. 1980. Classification and identification of bacteria by electrophoresis of their proteins, p. 273-297. In M. Goodfellow and R. Board (ed.), Impact of modern methods on classification and identification. Soc. Appl. Bacteriol. Symp. Ser. 8. Academic Press, London.

26. Lautrop, H. 1956. Gelatin-liquefying Klebsiella strains (Bacterium oxytocum [Flügge]). Acta Pathol. Microbiol. Scand. 39:375-384.

27. Marmur, J. 1961. A procedure for the isolation of deoxyribonucleic acid from micro-organisms. J. Mol. Biol. 3: 208-218.

28. Naemura, L. G., S. T. Bagley, R. J. Seidler, J. B. Kaper, and R. R. Colwell. 1979. Numerical taxonomy of Klebsiella pneumoniae strains isolated from clinical and nonclinical sources. Curr. Microbiol. 2:175-180.

29. Orskov, I. 1974. Genus VI. Klebsiella Trevisan 1885, p. 321-324. In R. E. Buchanan and N. E. Gibbons (ed.) Bergey's manual of determinative bacteriology, 8th ed. The Williams \& Wilkins Co., Baltimore.

30. Richard, C. 1973. Etude antigénique et biochimique de 500 souches de Klebsiella. Ann. Biol. Clin. 31:295-303.
31. Richard, C. 1977. Présence chez Enterobacter aerogenes d'antigènes capsulaires apparentés à ceux de Klebsiella. Intérêt de l'utilisation de meta-hydroxy-benzoate dans le diagnostic différentiel $E$. aerogenes-K. pneumoniae. Ann. Microbiol. (Inst. Pasteur) 128A:289-295.

32. Richard, R., B. Joly, J. Sirot, G. H. Stoleru, and M. Popoff. 1976. Etude de souches de Enterobacter appartenant à un groupe particulier proche de $E$. aerogenes. Ann. Microbiol. (Inst. Pasteur) 127 A:545-548.

33. Rohlf, F. J., and R. R. Sokal. 1969. Statistical tables, p 143. W. H. Freeman, San Francisco.

34. Schroeter, J. 1886. In F. Cohn (ed.), Kryptogamen Flora von Schlesien, vol. 3, p. 1-814. Pilze. J. U. Kern's Verlag, Breslau.

35. Silvestri, L., M. Turri, L. R. Hill, and E. Gilardi. 1962. A quantitative approach to the systematics of actinomycetes based on overall similarity. Symp. Soc. Gen. Microbiol. 12:333-360.

36. Skerman, V. B. D., V. McGowan, and P. H. A. Sneath. 1980. Approved lists of bacterial names. Int. J. Syst. Bacteriol. 30:225-420.

37. Steigerwalt, A. G., G. R. Fanning, M. A. Fife-Asbury, and D. J. Brenner. 1976. DNA relatedness among species of Enterobacter and Serratia. Can. J. Microbiol. 22:121-137.

38. Swings, J., K. Kersters, and J. De Ley. 1976. Numerical analysis of electrophoretic protein patterns of $Z y m$. omonas strains. J. Gen. Microbiol. 93:266-271.

39. Trevisan, V. 1877. Sul micrococco della rabbia e sulla possibilità di riconoscere durante il periodo d'incubazione dall'esame del sangue della persona morsicata, se ba contratta l'infezione rabbica. Rend. Ist. Lomb. Accad. Sci. Lett. (ser 2) 20:88-105. 